Filorofia Publiczna i Edukacja Demokratycina

Tom 1 • 2018 • Numer 2 / Tom 8 • 2019 • Numer 1 - Art. \#5 • s. 17-94

DO1: 10.14746/fped.2018.1.2.2019.8.1.5

Www.filozofiapubliczna.amu.edu.pl • ISSN 2299-1875

@) (reative Commons BY-NC-ND 4.0

\title{
The origins of postmodern moral relativism
}

\section{Gang Deng}

Abstruct: Postmodernism, which emerged in the 1960 s, involves a wide range of fields and carries out all-round critical reflections on the foundation, tradition and other aspects of the development of modern civilization. Postmodern morality came into being with the popularity of postmodernism in western countries. It features obvious "de-universality" and provides a new mirror for reflections on modern morality. Its progressive significance cannot be ignored. However, some postmodern moral concepts are becoming increasingly relativistic, even going to extremes, bringing about disturbances to society. Tracing the root of moral relativism back to ancient times based on the great history of its development, this study first sorts out the same gene of ancient Western moral relativism - using "skepticism" as a weapon against authority and dogmatism, and points out that the key of using moral relativism lies in seeking the proper limit of "skepticism". Then it draws forth the fact that postmodern morality started with "skepticism" and prevailed because of its "relativism", pointing out that some postmodern morality moved toward moral relativism because of persistence in "skepticism", while some fall into a state of moral nihility by radicalising "skepticism". If a craftsman wants to do good work, he must first sharpen his tools. This study concludes with suggestions on how to use the "skepticism" of postmodern morality.

Keywords: postmodern morality, moral and ethical relativism, skepticism, extremalization

\footnotetext{
* PhD Candidate at Foreign Literature and Culture Research Center, Guangdong University of Foreign Studies e-mail: 24I6894388@qq.com, 0RCID: 0000-0002-7972-1948
} 


\section{Introduction}

Relativism itself is a very complicated philosophy topic. Moral relativism is a special expression or individual case of relativism, the concept of which has not been defined exactly within academia. Postmodern morality learns from history, attacks on all sides with "skepticism", and doubts everything, showing an obvious tendency toward relativism. To illustrate this point, it has been stated that: "Morality arises when a group of people reach an implicit agreement or come to a tacit understanding about their relations with one another". ${ }^{1}$ Postmodern moral relativism carries out all-round criticism on the foundation, tradition and other aspects of the development of modern civilization, providing a new mirror for reflections on modern morality. It is progressive to some extent, but has exerted underestimated negative influence as well. Tracing the great history of moral relativism, this study first sorts out the same gene of ancient western moral relativism - using "skepticism" as a weapon against authority and dogmatism, and points out that the key of using moral relativism lies in seeking the proper limit of "skepticism". Then it presents the fact that postmodern morality started with "skepticism" and prevailed because of its "relativism", and thus points out that some postmodern morality moved toward moral relativism because of persistence in "skepticism", while some fall into a state of moral nihility by extremizing "skepticism". Finally, this study offers suggestions on how to use the "skepticism" of postmodern morality.

\section{The Origins of Ancient Western Moral Relativism}

\subsection{Extreme feelings}

Protagoras (circa 490 BC-420 BC) was an early ethical relativist thinker. City-states of ancient Greece in the 5th century BC embraced highly developed democracy, but ancient

1 Gilbert Harman, "Moral Relativism Defended", Philosophical Review 1975, vol. 84, no. 1, p. 3. 
Greek theology still prevailed. As a representative of sophists, Protagoras was the first to doubt theology and advocated his personal feelings. He said: "concerning the gods, I have no means of knowing whether they exist or not, nor of what sort they may be, because of the obscurity of the subject, and the brevity of human life." He dared to question powerful gods and mainstream thoughts, denied the role of gods, fate or other supernatural forces in life, and strongly supported the democracy of Athens, which had progressive significance. He emphasized the significance of human beings as the subject of understanding objective thoughts, discounted supra-natural influences, and thus, it could be argued, established human dignity. Protagoras even advocated "personalized" argumentation, arguing that if people use the methods of their opponent, then they cannot prove that they are better than others. ${ }^{2}$ Throughout his life, Protagoras lived in various places and was always respected. Unfortunately, he later took the role of "personal feelings" to the extreme and proposed that "man is the measure of all things, of the things that are, that they are, and of the things that are not, that they are not". According to him, everyone is the measure of all things. Then when people have different opinions, there is no objective truth to determine who is right and who is wrong. This theory is essentially a relativistic way of thinking, and it is based on "deceptive" feelings. Regarding feelings as the criterion of truth contains subjective idealism and ignores the role of morality and even law, which was not conducive to social stability at that time. The "extremalization" of Protagoras's relativism also brought him tragic consequences. His work On the Gods was burned and only a few fragments survived. He was expelled from Athens and then died on the way to Sicily.

\subsection{Extremaliation of contradictions between subjectivity and objectivity}

Gorgias (483 BC-375 BC) put forward skeptical propositions and systematized contradictions between subjectivity and objectivity. The main contents include three

1 Plato, Plato Complete Works (vol. 1), trans. by Wang Xiaochao, People's Publishing House, Beijing 2017, p. 458. 
propositions - nothing exists; even if something exists, nothing can be known about it; and even if something can be known about it, knowledge about it can't be communicated to others. He opposed the arbitrary authority of Parmenides of Elea's ontology with these three revolutionary propositions by profoundly exposing the contradictions between thinking and existence, and systematically laying out the contradictions between subjectivity and objectivity, between thinking and existence, and between language and thought. From this we can see that skepticism has always come from opposition to dogmatism. In the history of philosophy, Gorgias' three propositions have been discussed repeatedly and gained certain progressive significance. However, it is unfortunate that he took the "contradictions between subjectivity and objectivity" to the extreme. He believed that "knowledge is subjective and relative" and took this up as his imperative to demonstrate that "there is nothing". His view was extreme and directly manifested nihility. According to Gorgias, if communication between two people is possible, the listener and the speaker must be in the same state of mind, which is actually never impossible. Likewise, if we are to know what is outside the mind, the mind must be the same as the outside world. So, it is impossible to know what is outside the mind and to convey knowledge accurately from one person to another. Extremalizing the contradictions between subjectivity and objectivity is a kind of sophistry, which was regarded by Aristotle as misleading and deceiving the public. Under its influence, morality has no standards or even contents, and becomes a kind of nihilistic morality.

\section{The sleptical Pyrtho}

Pyrrho (circa 360 BC-circa 270 BC), who took dogmatism as enemy and sincerely believed in skepticism, saw dogmatism as the greatest threat. With skepticism as the method, he established thinking direction and principle, and applied this principle to practice. He introduced skepticism into philosophy as a theoretical form. He did not formulate a relatively systematic theory, but only laid the foundation of skeptics. Pyrrho's skepticism is indeed a rebellion against 
the dogmatism of natural philosophy, which made him the chief representative of ancient Greek skepticism. However, Pyrrho took skepticism to the extreme. He believed that each proposition can be opposed by an opposite proposition and that both had the same value and effectiveness and thus all claims cannot be established. This is outright skepticism. He exaggerated the relativity of feelings and cognition and although he did acknowledge the existence of phenomenon, he denied its reality. He believed that we can neither judge our feelings to be neither true or false, and therefore advocated epoche on all matters. This deeply entrenched skepticism led Pyrrho to be even skeptical about his own skepticism. This kind of skepticism is difficult to justify itself and therefore results in another kind of dogmatism. It does not believe in anything and does not make any judgments and perceives the outside world as completely irrelevant to its own, so as to maintain inner peace. Therefore, it can be viewed as being seriously out of touch with reality and it could be argued that such morality without "judgment", only "skepticism", would never lead to practical moral enforcement.

\subsection{Aenesidemus' personal feelings}

Aenesidemus (1st century BC-?) was one of the representatives who inherited Pyrrho's ideas. He put forward the "Ten Tropes for Epoche", namely: (1) Different creatures manifest different modes of perception. (2) Similar differences are seen among individual people. (3) For the same person, information perceived with the senses is self-contradictory. (4) Furthermore, it varies from time to time with physical changes. (5) In addition, this data differs according to local relations. (6) Objects are known only indirectly through such mediums as air, moisture, etc. (7) These objects are in a condition of perpetual change in colour, temperature, size and motion. (8) All perceptions are relative and interact one upon another. (9) Our impressions become less critical through repetition and custom. (10) All men are brought up with different beliefs, under different laws and social conditions. It is not difficult to see that he extremalized personal feelings. In this way, the relationship between individuals and society 
will exist only in name and morality is thus nothing. Morality that relativizes everything and only recognizes personal feelings cannot have similar moral enforcement goals and will only bring about social chaos in the end.

\section{The unattainable truth}

Sextus Empiricus (160 AD-210 AD) was a Greek doctor and philosopher. Although he was not an empiricist in philosophy, he was the last representative of ancient skepticism. He defined the basic principle of skepticism as "for every reasoning there is an equal and opposite reasoning". These two should neither be affirmed as true nor denied as false, because we did not know, nor could we know, which one was right. ${ }^{3}$ He pointed out in his works that people's feelings contradict each other, thoughts contradict each other, and feelings contradict thoughts. The so-called self-evident axiom is only hypothesis and its opposite is equally possible - therefore, truth cannot be attained. These conflicts and contradictions are therefore quite disturbing. So, this suggests that only by adopting a skeptical attitude, making no judgment and putting an end to all beliefs - can peace be achieved. Empiricus applied his works to refute the theories of different schools, which had certain progressive significance and so enriched the diversity of cognition. But he pushed the contradictions and conflicts in reality to the extreme and came to the conclusion that "truth cannot be attained", a typical negative skepticism, making his claim a reflection of the frustration of those in decline.

\subsection{The "silence" of moral relativism in the Middle Ages}

When it came to the Middle Ages, people advocated "love for God is the source of all power", combined the ancient "four virtues" with the religious "three Christian virtues", held humility for God and patience for the world, and also carried out asceticism, self-contempt and self-denial. Morality was engraved with religious elements and therefore could be said to have become hypocritical. Social morality was

3 Peter Burke, Montaigne, trans. by Sun Naixiu, China Social Sciences Press, Beijing 1992, p. 25. 
led to the relationship between man and God and provided people with spiritual comfort while completely enslaving the masses. Moral relativism and all other statements and thoughts contrary to sacred religion were completely suppressed. The "unification" of religious morality made it easy for people to be controlled and convenient for the rule of religion and feudal lords. As no questioning was allowed, it is not difficult to understand there was a "silence" of moral relativism in the Middle Ages.

\section{The Commonalities of Ancient Western Moral Relativism}

Western moral relativism is neither an independent ethical school nor a particular era in moral thought, but a longterm and universal tendency reflected in the developmental history of western moral thought. It brings together many ideological figures and theoretical schools spread throughout the entire history of the development of western moral thought. Born in ancient Greece, it was "silent" in the Middle Ages in Europe but flourished increasingly in the modern and postmodern age. Although western moral relativism thoughts showed different modes in different historical periods, there were some commonalities, mainly as follows: (1) Skepticism in what has no doubt; challenge absoluteness and hegemony with skepticism as a shield and sensibility as a spear. Their thoughts were, on the whole, characterized by "anti-center, irrationality, and uncertainty". (2) In the initial stage of skepticism, they gained a great deal of sympathy and obtained many advocates. Relativism is most likely to take root in the period when social thoughts are active or social history is in transition. (3) Western moral relativist thoughts easily turned from skeptical to extreme, from individual personality to confrontation and from pluralist to dispersion and finally - nihilism. Nihility and nihilism bring moral bankruptcy, chaos and instability, which is not allowed by rulers or even the general public. (4) The activity of moral relativism is inversely proportional to the management and control on social thought.

It is particularly noteworthy that for the moral relativism of each period, if it is "excessively skeptical" and goes 
to extremes, it can easily bring chaos to the concerned society. The reasons are as follows: (1) The danger of relativism lies not in "relativism", but in denying the possibility of mutual evaluation of values with "relativism". Because relativism tends to exaggerate subjectivity, absolutize relativism, and lead "suspicion" to extremes, thereby neglecting or even denying everything that exists objectively. Since ethical life and moral standards are relative, nothing is higher or lower and no one is right or wrong. (2) If individuals infinitely magnify desires under the disguise of "skepticism", it is bound to lead to the reversion (social disorganization) of human civilization, and finally to moral nihility. Without morality, the law of the jungle will reappear, which is against the original intention of human civilization. (3) Relativism is like a group of improvisational, free and romantic knights who ride the horse of "skepticism" and go on a rampage with inexhaustible hormones and insuppressible rebellious emotions. They sometimes do something good, and sometimes get into trouble.

\section{The Reappearance of Postmodern Moral Relativism}

Many scholars believe that postmodernism is a continuation and development of modernism. Although postmodern morality only began to gain ground in the public consciousness during the $1960 \mathrm{~s}$, relativism in postmodern morality can be traced back even earlier. From the perspective of historical development, the freedom pursued by postmodern moral relativism opposes traditional moral authority and moral tyranny. As for individuals and different groups, moral freedom provides a variety of moral development goals for people and fully meets the social and historical needs of development from the closed and unified Middle Ages to modern society.

\subsection{The re-emergence of moral relativism in the Renaissance}

The Renaissance from the middle of the 14th century to the beginning of the 17th century, also known as the period of first modernity, advocated the liberation of human subjectivity and the revival of skepticism. In the mid 16th century, 
a college student named Petrus Ramus first attacked Aristotle on epistemology and was recognized as a skeptic. Guy de Bruès, a young lawyer, imitated and developed Cicero's On Scholasticism, and mainly discussed knowledge and legal relativity. In 1576, the philosopher Francisco Sanchez (1523-1601) wrote an essay Nothing Is Known, in which he strongly criticized Aristotle and logicians in the Middle Ages ad ancient times. Francisco Sanchez's contemporary, Michel de Montaigne (1533-1592), wrote prose to stress various human ideas and their consequent unreliability. "It is impossible to find two opinions exactly alike" ${ }^{4}$ It is the principle of Montaigne's thought and doctrine to doubt everything and not make judgments, which leads to the reappearance of Pyrrho's thought. Moral relativism in the Renaissance was not popular but was a further supplement to the denial of theocracy, and a kind of beneficial thinking after the liberation of human nature. It promoted the enlightenment of human nature and had great significance for social progress. Skepticism is an attempt to find an "absolute truth" that transcends personal senses, universal opinions, and even scientific or mathematical theories. While the authenticity of all human cognition can be reasonably questioned, only the authenticity of "I" as the thinking subject cannot be questioned. In the history of western moral philosophy, "I think" as the foundation of moral philosophy had revolutionary significance and thus, Descartes came to us.

\subsection{The sleptical debate in the age of Enlightenment}

The subjectivity of "I think" determines Descartes' choice of "moral noumenon". In Descartes' opinion, "moral noumenon" exists in "spiritual entity", instead of "God entity", the "idea of good" or the abstract "principle of reason". Therefore, it could be argued that individual subjective thinking determines moral spirit. Grasping the relationship between individual subjective thinking and moral noumenon is a crucial link and element to understand the form and structure of Descartes' moral philosophy. The internal structure of the form of Descartes' moral philosophy can be

\footnotetext{
4 P. Burke, op. cit., p. 31.
} 
expressed as a "three-dimensional" structure: "spirit entity" - "moral freedom" - "subjectivity of 'I think". Kant's (1724-1804) ethical thought belongs to rationalistic ethics, which can be summarized as follows: people's moral life must be subject to a kind of principle, and this principle does not exist outside of people, but within their reason. All kinds of rationalistic ethics have a common view, that is, to understand "sovereign good" as a principle higher than the individual. This kind of morality believes that people's moral behavior obeys the order of reason. During the second modernity period (the age of Enlightenment), reason alone had its hegemony and reason was superior to everything. In the era of Logos, there was no God, no sensitive people, but only empty reasoning. Hume said, "so that when you pronounce any action or character to be vicious, you mean nothing but that, from the constitution of your nature, you have a feeling or sentiment of blame from the contemplation of it." What Hume did was to criticize and exclude the absolute leadership of "transcendental reason" in the construction of moral philosophy on the basis of "experience" and "observation". Hume reduced "reason" from "the master of the passions" to "the slave of the passions". "Reason is, and ought only to be the slave of the passions, and can never pretend to any other office than to serve and obey them." Moreover, when it comes to Berkeley, people will think of his statement; "esse est percipi" (to be is to be perceived). It means that the reason why something exists is that the composite idea of something is perceived by the subject. Berkeley's subjective relativism is the completion of Locke's empiricism. It can be said that thorough empiricism is necessarily subjective relativism. No wonder that in the 19th century, all traditional philosophy of empiricism was subjective idealism. In summary, relativistic ethics represented by Hume and Berkeley launched the debate on absolutistic ethics represented by Kant and others, which is also a manifestation of the increasingly strong "voice" of moral relativism in modern times.

s David Hume, A Treatise of Human Nature, trans. by Guan Wenyun, revised by Zheng Zhixiang, The Commercial Press, Beijing 2018, p. 505 . 


\section{Reflections on the era intertwined with beauty and udiness}

From the mid-19th century to the end of the World War II, social conditions were disappointing. The world was filled with wars, killings, capital, gap of wealth and anomie. From the standpoint of the will to power, Nietzsche held that the European civilization was on the decline and human beings were gradually degenerating. The root of the problem lied in Christian civilization. Nietzsche claimed that "God is dead", which appeared in his The Gay Science for three times and later in his famous work Thus Spoke Zarathustra. Traditional morality, he thought, with its powerful inertial force, deprived people of the ability to judge good and evil and let them be lazy to make moral judgment. "When I came to men, then I found them resting on an old infatuation: all of them thought they had long known what was good and bad for men." ${ }^{6}$ Nietzsche's contribution to ethics is his attempt to find a third way above religious asceticism, modern utilitarianism and hedonism. Only by not blindly following the consensus of the public, not blindly following the subjectivity of public interests, not following the subjectivity of traditional interests, and not following the path of traditional mediocrity, can a person truly strive to give full play to the subjectivity of his own interests, find the meaning of his life, and invent his own correct moral life. From these we can see Nietzsche's skeptical spirit. He did not follow the certainty of absolute authority or believe in the absolute myth of collectivism. The subjectivity of interests as understood by Nietzsche is the subjectivity of individual interests, instead of the subjectivity of public interests. He believed that there was no subjectivity of human interests, but only the subjectivity of individual interests. Although these efforts were not successful, he raised enlightening questions for human beings, which greatly influenced the development of postmodernism, especially the further development of relativism. He put forward a kind of real morality which promotes human nature and benefits human development, namely the superhuman morality. Nietzsche's morality is characterized by moral innovation and

6 Friedrich Nietzsche, God Is Dead. Selected Writings of Nietzsche, trans. by Qi Ren. Joint Publishing House Press, Shanghai 1989, p. 122. 
some elements of old morality, including relativity. Just like being in the transition from rational modernism to postmodernism and then new postmodern morality.

\section{Some Relativism Tendency and Extreme Expression in Possmodern Morality}

Postmodernists believe that since the Enlightenment, reason development led by rationalism has been transformed into instrumental rationality, and that the sacred mission of human beings to pursue mind freedom and liberation has been dominated by scientific and technological civilization, thus resulting in alienation and materialization. Therefore, postmodernism rejects the ideas of wholeness, certainty, universality and unity pursued by modernity and emphasizes opposite arguments such as difference, uncertainty, diversification, local theory and dynamics. When modernity comes to self-criticism and self-demolition, the path followed by many previous ethical theories starts to look like a blind path, and at the same time, the door is opened to the possibility of a radical and novel understanding of moral phenomena. ${ }^{7}$ Therefore, people put their hopes on "new reformers" (postmodernism). In general, postmodern morality holds an incredulous attitude towards logical concept and structural interpretation. Historical experience shows that this kind of attitude easily leads people to their lack of desire for thoughts, things and external feelings, thereby resulting in relativism. The result is often that, except skepticism, their thoughts are almost frozen. They are sometimes like wandering and aimless reformers, riding the horse of skepticism to go on a rampage, achieving nothing and only doubting everything.

\subsection{The destructive power of relativism and the reduction of moral universality}

Emphasis on moral universality is the basic characteristic and argument pillar of western modern ethics, but the reality of modern society is cruel. Science and technology created by man in turn control man's thoughts, behavior and cultural

1 Zygmunt Bauman, Postmodern Ethics, trans. by Zhang Chenggang, Jiangsu People's Publishing House, Jiangsu 2003, p. 2. 
life. Man has to exchange rich external material benefits for inner spiritual degradation, leading to man as being alienated. Thus, it could be argued that the result of modern morality is disappointing. The rationality and legitimate crisis of western modern ethnics provide an opportunity for the rise of postmodern ethics in the west. Postmodernism is famous for its skepticism about scientific rationality and is highly expected. While destroying the edifices of western modern ethics, western postmodern ethics drives modern morality away from the altar of universality and unity and reduces it to the facts of human's moral life, such as diversified moral experience, extensive moral divergence and profound moral and cultural difference, and thoroughly particularizes it. "Most people's values reflect conventions that are maintained by continual tacit bargaining and adjustment." ${ }^{8}$ It advocates diversified moral experience, extensive moral divergence and profound moral and cultural difference, which are seemingly new and thus popular among the people. It exists in people's expectations, as if it has become the great "savior" to "save the mess left by modernism morality". Unfortunately, postmodern morality is overjoyed and overproud, it questions everything, even itself, and going to the extreme of relativism. The result must be the reduction of moral universality. The main manifestation is that morality is no longer the essential need of human beings. Without moral principle of universal effectiveness, there is no fundamental standard to judge the good and evil nature of human behavior, let alone moral practice.

\subsection{The discourse power of relativism and the contextudiliation of moral norms}

The most glorious "debut" and "power claim" of postmodernism trend after the World War II also enabled relativism to secure and all-round "status" in many varied realms, such as; politics, economy, culture, thought, philosophy, folk custom etc. It was unbeatable. The relativism tendency in postmodern morality was increasingly prevalent. "Our age is often called the age of relativism." Postmodern

8 G. Harman, „Responses to Critics”, Philosophy and Phenomenological Research 1998, vol. 58, no. 1, p. 164.

9 Luther J. Binkley, Conflict of Ideals, trans. by Ma Yuande et al., The Commercial Press, Beijing 1983, p. 6. 
relativism morality holds that people's moral concepts, moral judgments and moral choices should be judged completely according to the "context" within a specific time, and that the result of such judgment is inevitably based on a specific context as the starting point of theory and practice. This is obviously one-sided and mechanical, because it only sees individual particularity in the specific moral situation and ignores the existence of a universal and valuable moral practice in the great history of human society. In the west, the values clarification school can be the best example of following moral relativism. As said by Dewey in his book Moral Principles in Education, morality is generated by adapting to the context, and one kind of morality is good for one environment, but not for others. This kind of moral cognition and moral judgment is separate from individual personality and moral self. And this separation leads to the fact that although a person may have good moral cognition and moral judgment, he may not know a choice in what kind of context is a moral choice and a behavior in what kind of context is a moral behavior. If moral judgment departs from people's moral quality, it is likely to deviate from the construction of moral self. If we advocate a normative "contextualized" morality, when people face the ever-changing "context" in society, they can only make their own decisions, and the consequences can be disastrous.

\section{The extremalization of relativism and the thorough differentiation of moral values}

As Steven Lukes puts it, moral relativism remains attractive because, in fact, it acknowledges the idea that there is no single best way to live one's life. ${ }^{10}$ Since there is no single best way to live, it is up to the individual to decide which way to live. MacIntyre believed that the crisis of modern morality and modern society lied in the radicalisation of moral relativism, and that the loss of traditional human virtue lead to the loss of objective and impersonal moral standards. The price of moral actors' liberation from the external authority of traditional morality is that any so-called moral words

10 Steven Lukes, Moral Relativism, trans. by Chen Rui, China Legal Publishing House, Beijing 2013, p. 158. 
of the new self-discipline actors lose all authoritative contents. All moral actors can express themselves without being constrained by the authority of the law of external Gods, the teleology of nature, or hierarchy. ${ }^{11}$ Extreme moral relativism believes that all morality is relative, value is subjective and individualized, morality is a personal matter and that everyone's independent value choice has legitimacy. This kind of morality will inevitably bring about the complete differentiation of social value and bring more accidental and ambiguous experiences to people, which can easily cause moral loss and moral decay, something worth reflecting on.

In the view of values clarification school, what matters is the formation of value and the process of obtaining value, rather than what kind of value is right and what kind of value should be cultivated for students. The burden of ethical choices is being placed on individuals more than ever..$^{12}$ Extreme relativism or skepticism holds that the control over power is ineffective and should be opposed, and that the ultimate source of moral value is not the basis of culture or reason but the individual. The existence of any impersonal, universal and objective moral authority will lose its legitimacy basis, value will be thoroughly differentiated, and moral thought will eventually transform into nihility. There is no doubt that relativism value, if it is true and believed, will plunge people into mental confusion and an extremely dangerous political game. ${ }^{13}$ This is the internal pain that moral relativism itself cannot overcome.

\section{Looking Back on History, the Tree of Skepticism Is Evergreen}

Adhering to skepticism is a prominent feature of relativism, but postmodernists should not advocate unbridled skepticism or encourage extreme relativism. In general, many postmodern western ethicists do not deny the normative

" Alasdair MacIntyre, After Virtue, trans. by Gong Qun et al., China Social Sciences Press, Beijing 1985, p. 87.

". David Lyon, Postmodernity, trans. by Guo Weigui, Jilin People's Publishing House, Jilin 2004, p. 7.

B Allan Bloom, The Closing of the American Mind, trans. by $\mathrm{Mu}$ Qing et al., China Social Sciences Press, Beijing 1994, p. 156. 
nature of morality, "It is compatible with moral relativism for certain moral claims to hold in relation to all moral frameworks just as certain claims about motion hold in all spatio-temporal frameworks"14, which is worth affirming. But if relativists push skepticism to the extreme, simply deny everything and ignore the existence of others, it is not appropriate morality. Morality is supposed to guide people to make a right choice, but it becomes impossible under extreme relativism. What's more, once ethics and moral education no longer pay attention to the substantial value of morality, the pursuit of excellent quality will lose its legitimacy in the moral system, and the indoctrination value of moral education will be difficult to realize. The skepticism advocated by relativism is of progressive significance and is a necessary weapon to deconstruct one-way hegemony. However, just as alcohol is to people, this concept should be used appropriately, otherwise, it can cause harm.

Skepticism is a science, or even the beginning of an innovative inquiry, but it is by no means a simple denial. Just skepticism is not a sin and should be encouraged, even approved. Skepticism is a state of mind. It is supervision, inspection, reflection and feedback in actions. Skepticism can be a germinating seed and a channel for innovation. Morality is always the dialectical unity of relativity (particularity) and absoluteness (universality). The relativity of morality implies the absoluteness of morality. Moral norms and customs are historical, national and contemporary, which is inevitable for all morality, and this is the relativistic side of morality. But relativity (particularity) always implies absoluteness (universality). Rousseau once said, look at the nations of the world and look at the history: in many unnatural and weird worship forms, in many different customs and habits, you can find the same moral principle and the same idea of good and evil everywhere. Today, with globalized social development and increasing promotion of individual freedom in postmodernism, supporters of postmodern morality should remember that while advocating individuation, they cannot ignore the universality of moral particularity. Only when we strike a balance between relativity and

\footnotetext{
14 G. Harman, „Responses to Critics”, p. 209.
} 
absoluteness can we make our skepticism benefit human civilization and the tree of skepticism remains evergreen.

\section{Condusion}

Although the relativism tendency of postmodern morality is by no means useless, it can go to the extreme very easily. People must be cautious in this regard. Appropriate relativism is conducive to the cultivation of individual and group moral freedom. It enables us to adopt an open-minded and flexible attitude, helps people of different nations, cultures and social systems form an atmosphere of mutual respect, mutual understanding and mutual tolerance and facilitates equal exchanges between different cultures. However, on the one hand, postmodern morality is faced with the challenges of value individualism and moral relativism tendency thereof. If relativism is further extreme, it can go from "skepticism" to moral "nihility". On the other hand, if social moral education excessively takes moral relativism as the theoretical support for its existence and development and pursues extreme value neutrality, instead of value-led personal integrity and mission, the final consequence is usually that moral education loses moral quality and the nature of spiritual education and moral education may become non-moral. The dialectical unity of moral absoluteness and relativity requires people to adhere to the moral development goal of "harmonious coexistence", learn from each other, enhance consensus and make efforts to form effective universal ethics.

\section{Bibliography}

Bauman Z., Postmodern Ethics, trans. by Zhang Chenggang, Jiangsu People's Publishing House, Jiangsu 2003.

Binkley L.J., Conflict of Ideals, trans. by Ma Yuande et al., The Commercial Press, Beijing 1983.

Bloom A., The Closing of the American Mind, trans. by Mu Qing et al., China Social Sciences Press, Beijing 1994.

Burke P., Montaigne, trans. by Sun Naixiu, China Social Sciences Press, Beijing 1992.

Harman G., "Moral Relativism Defended", Philosophical Review 1975, vol. 84, no. 1 . 
Harman G., „Responses to Critics”, Philosophy and Phenomenological Research 1998, vol. 58, no. 1.

Hume D., A Treatise of Human Nature, trans. by Guan Wenyun and revised by Zheng Zhixiang, The Commercial Press, Beijing 2018.

Lukes S., Moral Relativism, trans. by Chen Rui, China Legal Publishing House, Beijing 2013.

Lyon D., Postmodernity, trans. by Guo Weigui, Jilin People's Publishing House, Jilin 2004.

MacIntyre A., After Virtue, trans. by Gong Qun et al., China Social Sciences Press, Being 1985.

Nietzsche F., God Is Dead. Selected Writings of Nietzsche, trans. by Qi Ren, SDX Joint Publishing House Press, Shanghai 1989.

Plato, Plato Complete Works, vol. 1, trans. by Wang Xiaochao, People's Publishing House, Beijing 2017. 